\title{
Backyard poultry in Kabylie (Algeria): from an indigenous chicken to a local poultry breed?
}

\author{
N. Moula ${ }^{1}$, F. Farnirir ${ }^{1}$ A. Salhi' ${ }^{2}$ M. Iguer-Ouada ${ }^{3}$, P. Leroy $^{1}$ and N. Antoine-Moussiaux ${ }^{1}$ \\ ${ }^{I}$ Department of Animal Production, Division of Genetics and Biostatitics, Faculty of Veterinary Medicine, University of Liege, \\ Boulevard de Colonster 20 B43, 4000 Liege, Belgium; ${ }^{2}$ Department of Mathematical Sciences, University of Essex, Wivenhoe Park, \\ Colchester CO4 3SQ, UK; ${ }^{3}$ Department of Organism and Populations Biology, Faculty of Life and Nature Sciences, University of \\ Abderahmane Mira, Bejaia 06000, Algeria
}

\begin{abstract}
Summary
Backyard poultry is considered as a powerful tool for poverty alleviation. It is further promoted as a way of empowering women in communities where there is gender bias in poultry raising. The low-input systems involved are based on local breeds that are perfectly suited to their environment. However, socio-economic processes put local genetic resources under pressure, leading to the erosion of biodiversity. The present survey addresses this issue in the case of Kabylie, a mountainous coastal region of Algeria, through a survey conducted in 90 households raising poultry, a morpho-biometric description of 315 local chickens, and a performance evaluation of both growth and egg production in experimental semi-intensive conditions. The socio-economic profile of poultry smallholders in Kabylie reveals poor education and high diversification of agricultural assets and confirms gender bias in poultry keeping. The erosion of local genetic resources in chicken is found to be severe despite their cultural importance in Kabylie. From complementary surveys among experienced poultry keepers, the major original local type is postulated to consist of three varieties with black plumage (pure black, mottled and barred). The performance evaluation raised promising results, suggesting that exploiting the local breed could pursue some degree of improvement of low-input backyard systems. Finally, a strategy for a revival of the local breed through the support of the most involved smallholders is outlined in accordance with the information collected in the survey.
\end{abstract}

Keywords: biodiversity, genetic resources, Kabylie, poultry, smallholder

\section{Résumé}

L'élevage de volailles d'arrière-cour constitue un outil important de lutte contre la pauvreté. Il est en outre promu comme mode de renforcement de la position féminine dans une communauté, sous réserve de l'observation dans les faits du biais de genre classiquement rapporté dans le contrôle de cet élevage. Les systèmes à faible niveau d'intrant concernés sont basés sur des races locales rustiques, adaptées à leur environnement. Néanmoins, des processus socio-économiques mettent sous pression ces ressources génétiques locales, menant à une érosion de la biodiversité. La présente étude aborde cette problématique dans le cas de la Kabylie, région côtière montagneuse de l'Algérie, au travers d'une enquête auprès de 90 ménages élevant des poules, d'un relevé morpho-biométrique réalisé sur 315 sujets locaux ainsi qu'une évaluation des performances de ponte et de croissance dans des conditions semi-intensives expérimentales. Le profil socio-économique des petits éleveurs de poules en Kabylie révèle un faible niveau de formation, une grande diversification de l'outil agricole et confirme le biais de genre mentionné plus haut. Une érosion génétique sévère a été trouvée, en dépit de l'importance culturelle de la poule en Kabylie. Une enquête complémentaire auprès d'éleveurs expérimentés indique que trois variétés de plumages noirs (noir pur, caillouté, barré) sont considérées comme constituant les principaux types locaux d'origine. L'évaluation des performances a fourni des résultats prometteurs, suggérant qu'un certain degré d'amélioration des systèmes d'élevage d'arrière-cour pourrait être recherché sur base des types locaux. Finalement, en accord avec l'information recueillie dans cette enquête, une stratégie de revivification de la race locale au travers d'un soutien aux éleveurs les plus impliqués est brièvement proposée.

Mots-clés: biodiversité, ressources génétiques, Kabylie, poule, petit éleveur

\section{Resumen}

La cría de aves de traspatio es considerada como una poderosa herramienta para mitigar la pobreza. Además, es promovida como una forma de dotar de mayor poder a las mujeres en las comunidades donde existe una discriminación de género en la crianza de aves de corral. Los sistemas de bajos insumos en juego están basados en las razas locales, adaptadas a su entorno. Sin embargo, los diferentes procesos socioeconómicos acaecidos han sometido a presión los recursos genéticos locales, dando lugar a la erosión de la biodiversidad. El presente estudio aborda esta cuestión en el caso de Cabilia, una región montañosa de la costa de Argelia, a través de una encuesta realizada a 90 familias que crían aves de corral, una descripción morfométrica de 315 animales pertenecientes a poblaciones locales, y una evaluación del rendimiento relacionado con el crecimiento y la producción de huevos bajo condiciones experimentales semi-intensivas. El perfil socio-económico de los pequeños productores de aves de corral en Cabilia revela falta de educación y alta diversificación de los activos agrícolas, confirmando la discriminación de género en la tenencia de este tipo de aves. La erosión de los recursos genéticos locales relativos a las aves de corral es muy grave, a pesar de de la importancia cultural de éstos en Cabilia. Tomando como base encuestas complementarias, entre aquellos avicultores con mayor grado de experiencia, se presupone que el tipo original 
local más importante consta de tres variedades de plumaje negro (negro puro, moteado y barrado). El estudio de los rendimientos ha aportado prometedores resultados, indicando que la cría de razas locales puede dar pie a cierta mejora de los sistemas de traspatio de bajos insumos. Por último, de acuerdo con la información recogida a través de la encuesta, se esboza una estrategia para apoyar el restablecimiento de las razas locales, contando con el apoyo de la mayoría de los pequeños agricultores.

Palabras clave: biodiversidad, recursos genéticos, Cabilia, ave de corral, pequeño agricultor

Submitted 7 September 2011; accepted 6 December 2011

\section{Introduction}

Proteo-caloric malnutrition is a widespread consequence of poverty in developing countries, further compromising people's capability to step out of their condition. In this regard, backyard poultry can be an important tool in poverty alleviation, as eggs for home consumption are a lowcost protein source especially valuable for children's growth, or as it can provide additional income where markets are available (Mack, Hoffmann and Otte, 2005; Roothaert, Ssalongo and Fulgensio, 2011). In Algeria, as in other regions of the developing world, beyond this productive role, poultry moreover plays a pivotal role in the social sphere, being sacrificed at important occasions such as weddings and circumcision ceremonies or being offered to special guests (Moula et al., 2009a; Raach-Moujahed, Moujahed and Haddad, 2011). Therefore, poultry can be considered as addressing the poverty problem in its multidimensional nature. The link between poultry and poverty alleviation is even more clearly expressed in the case of Kabylie where the poor are traditionally said to be "the one who does not even have a hen." Indeed, in contrast to larger animals such as ruminants or pigs, poultry is characterized by the low investment needed in backyard systems. Thus they often represent the first step in capitalization by poor people.

Unfortunately, the local breeds on which those low-input systems are based are presently endangered owing to the spread across rural areas of commercial hybrid strains from their initial intensive rearing spots. At present, half of the poultry breeds of known status are at risk of extinction (FAO, 2008). Poverty in itself is a basic explanation for this genetic erosion: backyard poultry breeders introduce highly productive and genetically uniform strains in their indigenous flocks according to a short-term gain strategy at the expense of sustainability (Anderson, 2003). Indeed, the lack of adaptation of these hybrid strains to the village raising practices induces a major risk to the present and future production system without realizing the expected profit. A more long-term-oriented strategy should consist of a progressive upgrading of the rearing systems, including the genetic improvement of the local breeds in accordance with the locally available inputs and environment control capacities and possible qualitative and cultural expectations. In this context, characterization of local breeds and assessment of their productive potential in their actual raising system as well as their response to an upgrading of this system is crucial. The present study aims at such an evaluation in Algeria.

\section{Materials and methods}

\section{General structure of the study}

Characteristics of backyard poultry raising were assessed in a sample of 30 villages of Basse-Kabylie, a mountainous costal region of Algeria about $200 \mathrm{~km}$ east of Algiers. The study villages were chosen in ten districts, spreading over the north (2), center (2), south (2), east (2) and west (2) of the region. The raising systems were first assessed through a socio-economic survey conducted in 3 households per village (90 households interviewed). Morpho-biometric characterization of 315 local chicken specimens was then completed. Finally, growth and laying performances were assessed in semi-intensive conditions for 111 chicks and 50 hens, respectively.

\section{Socio-economic survey}

Age, sex, education level, occupations and agricultural endowment of the respondent and the members of the household were recorded. Open questions related to poultry raising practices. Respondents were then asked about their motivations for chicken rearing in general and for the choice of the local breed in particular as well as for the use of the different products through three multiplechoice questions.

In the additional survey, 14 interviewees with over 50 years experience in poultry raising were asked an open question about their perception of a possible change in chicken genetic resources kept in their village (period, nature of the change, description of the former phenotypes).

\section{Morpho-biometric characterization}

Adult animals ( $>10$ month) were exclusively used for the morpho-biometric characterization. The different body measurements were recorded in accordance with the FAO (1981) recommendations, by means of a digital balance (accuracy $1 \mathrm{~g}$ ), an electronic sliding calliper (accuracy 
$0.01 \mathrm{~mm}$ ) and a tape measure. The data collected were sex, body weight and reported age of the animal; thoracic girth; feathers type and colour; comb's type, length, height and colour; wattles' height and colour; tarsus length and diameter; wings' length; and the length and colour of the beak.

\section{Egg production performance}

Eggs collected in the different villages were put for natural incubation and hatching. Day 1 chicks were vaccinated against Marek's disease. The chicks were then kept in a brooder house and fed a commercial starter mix (22 percent crude protein, $2700 \mathrm{kcal} / \mathrm{kg}$ metabolizable energy) ad libitum until 12 weeks of age. A commercial growth mix (18.9 percent crude protein, $2700 \mathrm{kcal} / \mathrm{kg}$ metabolizable energy) was then given for the following weeks. Temperature and relative humidity were not kept constant but were recorded daily. Maximum temperature ranged between 24 and $32{ }^{\circ} \mathrm{C}$ and minimum temperature between 19 and $26^{\circ} \mathrm{C}$. Maximal relative humidity varied from 60 to more than 94 percent and minimal from 45 to 80 percent.

At week 18, a total of 60 hens were transferred to individual cages. Natural lighting duration was $12 \mathrm{~h} 15$ at week 19 and was then increased by increments of 30 min per week till duration of $16 \mathrm{~h} 30$ light per day at week 26 . Ranges for maximal and minimal temperature as well as for maximal and minimal relative humidity were $12-31^{\circ} \mathrm{C}, 6-14^{\circ} \mathrm{C}$, 75-96 and 50-83 percent, respectively. A laying hen feed mix (18.9 percent crude protein, $3060 \mathrm{kcal} / \mathrm{kg}$ metabolizable energy) was given from week 20 (composition shown in Table 1). Ten animals died during the

Table 1. Feed mix composition for starting, growth and laying.

\begin{tabular}{|c|c|c|c|}
\hline \multirow[t]{2}{*}{ Ingredients } & \multicolumn{3}{|c|}{ Mix } \\
\hline & $\begin{array}{l}\text { Broiler } \\
\text { starter }\end{array}$ & Broiler & $\begin{array}{l}\text { Layer } \\
\text { hens }\end{array}$ \\
\hline Soy oil cake & 32 & 30 & 20.0 \\
\hline Wheat & 37 & 31 & 11.0 \\
\hline Corn & 25 & 33 & 50.0 \\
\hline Soy oil & 2.3 & 2.0 & 3.0 \\
\hline Calcium phosphate & 1.5 & 1.8 & 1.0 \\
\hline Minerals (vitamins, micronutrients) ${ }^{1}$ & 1.1 & 1.0 & 1.0 \\
\hline Calcium carbonate & 1.08 & 1.2 & 7.5 \\
\hline Methionine & 0.02 & 0.2 & 0.1 \\
\hline Alfalfa & - & - & 2.4 \\
\hline Beets molasse & - & - & 1.5 \\
\hline Wheat middlings & - & - & 2.5 \\
\hline \multicolumn{4}{|l|}{ Composition } \\
\hline Metabolizable energy $(\mathrm{kcal} / \mathrm{kg})$ & 2870.00 & 2950.00 & 3060.40 \\
\hline Fat content $(\mathrm{g} / \mathrm{kg})$ & 55.13 & 52.18 & 54.53 \\
\hline Lysine $(\mathrm{g} / \mathrm{kg})$ & 12.45 & 8.46 & 11.28 \\
\hline Methionine $(\mathrm{g} / \mathrm{kg})$ & 5.39 & 3.45 & 4.36 \\
\hline Calcium $(\mathrm{g} / \mathrm{kg})$ & 9.5 & 38.0 & 10.00 \\
\hline Phosphorus (g/kg) & 6.03 & 5.62 & 5.68 \\
\hline Dry matter (g/kg) & 612.9 & 749.6 & 561.26 \\
\hline Crude protein $(\mathrm{g} / \mathrm{kg})$ & 220 & 170 & 189.00 \\
\hline
\end{tabular}

${ }^{1}$ Vitamin A $13500 \mathrm{UI} / \mathrm{kg}$, vitamin $\mathrm{D}_{3} 3.000 \mathrm{UI} / \mathrm{kg}$, vitamin E $25 \mathrm{mg} / \mathrm{kg}$, copper sulphate $15 \mathrm{mg} / \mathrm{kg}$. experiment, of unknown cause, as necropsies could not be carried out.

\section{Laying records}

Age and weight of the hens at the onset of laying were recorded. Laying was followed-up daily and individually for 52 weeks. Cumulative egg laying rate was assessed for two periods: from week 38 to 42 and from week 56 to 60 .

\section{Egg quality}

Egg quality analysis was implemented at both abovementioned periods by weekly collection of the first three eggs for each hen (1 500 eggs). Analysis was completed within a few hours after laying. Eggs were numbered and weighed to the nearest $0.01 \mathrm{~g}$. Then, their length and width were measured by means of an electronic sliding calliper (accuracy $0.01 \mathrm{~mm}$ ), so that an egg shape index could be calculated (ratio between length and width) (Moula et al., 2010). The eggs were then broken with careful separation of yolk and albumen. The shell (including membranes) and yolks were weighed separately (accuracy $0.01 \mathrm{~g}$ ). Albumen weight was determined by subtracting yolk and shell weights from total egg weight. The shell thickness was measured at three different random points in the equatorial shell zone using an electronic micrometre (accuracy $0.01 \mathrm{~mm}$ ). The average of the three measures was used as a trait (Moula et al., 2010).

\section{Growth performance}

A total of 160 eggs were put for natural incubation by 16 selected hens with acknowledged brooding ability. Hatching rate was recorded. The chicks $(n=111)$ were floor-bred on a sawdust litter in a same ventilated building (no air conditioning). Chicks were first put under a heating lamp and the room temperature was regulated manually according to chicks' behaviour. A continuous light regimen was adopted for the whole experiment period. Animals were fed ad libitum with a starter mix until the age of 14 days (22 percent crude protein, $2870 \mathrm{kcal} / \mathrm{kg}$ metabolizable energy) and then passed to a tradition poultry mix (20 percent crude protein, $2950 \mathrm{kcal} / \mathrm{kg}$ metabolizable energy) which was given ad libitum until slaughter (feed composition listed in Table 1).

Each animal was identified individually. After sexing at week 9, males and females were kept separated by a metallic net. Animals were weighed individually at week 0,1 , 4, 8, 12 and 16. The feed conversion index was assessed for the flocks by calculating the ratio between the total ingested food and total live weight gain.

\section{Statistical analysis}

All statistical analyses were performed with the SAS software (Statistical Analysis System, 2000). 
Socio-economic and morpho-biometric surveys Descriptive statistics were obtained for all socio-economic and morpho-biometric parameters. Answers to the multiple-choice questionnaire were analysed in terms of frequency of occurrence (citation rate).

\section{Egg laying performance}

Descriptive statistics (frequency, mean, standard deviation) were calculated for the following parameters: hatching rate, weight and age at onset of laying, laying rates, annual number of eggs laid per hen. Student's $t$-test was performed in order to compare data obtained for the two different laying periods (weeks $38-42$ and weeks 56-60).

\section{Growth performance}

Mean body weight by sex was calculated for each week along with standard deviations. Growth was further described by the calculation of growth curve parameters according to the following Gompertz equation: $y=\alpha \times$ $\exp (-\beta \times \exp (-\gamma \times t))$, where $y$ is the weight of broiler $(\mathrm{g}) ; \alpha$ is the asymptotic weight; $\beta$ is the integrating constant; $\gamma$ is the growth speed factor (maturation factor) and $t$ is the time (Porter et al., 2010). These parameters were estimated by non-linear regression using the Marquardt method in the Non-linear Models Procedure of SAS (2000). The age to inflexion, corresponding to the period when growth is maximum, was calculated using the formula: $T_{i}=(1 / \gamma) \times \ln |\beta|($ Porter et al., 2010) .

\section{Results}

\section{Socio-economic characteristics of local poultry keepers}

Median number of poultry by household was 11. Among the 90 respondents, 57 were men and 33 women. The men responding were effectively in charge of poultry keeping activities in only 17 households, poultry keeping being mainly a female occupation (81 percent of households).
This means that 40 women involved in poultry keeping could not be directly interviewed because of the husband's intervention. In all households, women were housewives. Men's main occupation was agriculture in 37 percent of the households; 14 percent were civil servants, 9 percent were merchants and 7 percent were transporters. In 33 percent of households, men declared to be in a situation of unemployment. However, all households of the latter category did present agricultural occupations. Education level was globally low, especially in women; 64 percent of women were illiterate. Among men, 79 percent did not obtain the basic school certificate. Two noticeable exceptions were agronomists (university degree) that were employed as civil servants and were actually in charge of the poultry keeping activities in their household. For the complementary survey among experienced raisers, the median age of respondents was 69.5 years with a minimum at 60 and a maximum at 91 .

\section{Agricultural assets}

Besides poultry keeping, 79 percent of households cultivate small plots. The major crops are cereals (wheat or barley) and some vegetables (tomatoes, beans, potatoes, onions, courgettes, etc.). Production is generally aimed at home consumption. Owing to the mountainous environment of Kabylie, fruit trees are a common agricultural capital owned by households. The most common trees are olive trees and fig trees, owned by 93 and 88 percent of interviewed households, respectively, but 94.5 percent of households also own other fruit trees such as apple, cherry, orange trees or even oaks (the acorns of which are both consumed by man and fed to animals). Beekeeping was practiced by 62 percent of the households. Fruit trees and beehives are both commonly situated on plots owned by other households, their tenure thus being independent of that of the land harbouring them. The other animals kept were sheep (86 percent), rabbits (64.5 percent), goats (44.5 percent), cattle (38 percent), turkeys (25.5 percent) and ducks (20 percent) (Table 2$)$.

Table 2. Mean stocks by species and by sex in the surveyed households.

\begin{tabular}{|c|c|c|c|c|c|c|}
\hline Species & $\% \mathbf{H H}$ & Sex & Mean stock by $\mathrm{HH} \pm \mathrm{SE}$ & Lowest stock & Highest stock & CV $(\%)$ \\
\hline \multirow[t]{2}{*}{ Poultry } & 100.00 & Male & $2.57 \pm 0.14$ & 1 & 6 & 50.13 \\
\hline & & Female & $9.52 \pm 0.46$ & 2 & 21 & 45.41 \\
\hline \multirow[t]{2}{*}{ Sheep } & 86.67 & Male & $3.08 \pm 0.53$ & 1 & 23 & 146.17 \\
\hline & & Female & $9.06 \pm 0.87$ & 2 & 42 & 84.70 \\
\hline \multirow[t]{2}{*}{ Rabbit } & 64.44 & Male & $2.88 \pm 0.53$ & 1 & 23 & 133.76 \\
\hline & & Female & $9 \pm 0.89$ & 2 & 42 & 75.30 \\
\hline \multirow[t]{2}{*}{ Goat } & 44.44 & Male & $1.82 \pm 0.17$ & 1 & 6 & 58.47 \\
\hline & & Female & $6.62 \pm 0.65$ & 2 & 21 & 62.16 \\
\hline \multirow[t]{2}{*}{ Cattle } & 37.78 & Male & $2 \pm 0.30$ & 1 & 8 & 85.19 \\
\hline & & Female & $6.18 \pm 0.97$ & 1 & 28 & 91.71 \\
\hline \multirow[t]{2}{*}{ Turkey } & 25.56 & Male & $3.13 \pm 0.45$ & 1 & 6 & 68.31 \\
\hline & & Female & $7.35 \pm 1.21$ & 2 & 23 & 78.99 \\
\hline \multirow[t]{2}{*}{ Duck } & 20.00 & Male & $1.33 \pm 0.11$ & 1 & 2 & 36.38 \\
\hline & & Female & $4.17 \pm 0.42$ & 2 & 8 & 42.97 \\
\hline
\end{tabular}

$\% \mathrm{HH}$ : percentage of households holding a particular species; $\mathrm{CV}$ : coefficient of variation. 
Motivational aspects and poultry genetic resources management

The major motivations cited for poultry keeping were egg production (58 percent), tradition (53 percent) and then meat production (52 percent) (Table 3 ). Rationale for the preference of keepers for the local chicken is presented in Table 3. The most cited reasons were the strong flavour of its meat (89 percent) and the resilience of the birds to harsh environment (73 percent). The ease of daily care was also commonly cited (65.5 percent).

The 14 experienced respondents, all raising poultry for more than 50 years, unanimously reported a noticeable change in the poultry genetic resources in their villages. The period at which they situate the beginning of this change is the early 1990s. The nature of the change discussed is a widening of phenotypic variability, a decrease in flock size and a loss in "quality" and flavour of both meat and eggs. All respondents described the original phenotypes as predominantly black with some white in the plumage (pure black, mottled or barred) and with blue or black legs. Ten of them also mentioned the partridge plumage along with the black and white varieties as the "true Kabyle chickens". Six persons also cited the blue plumage. The greater resistance to diseases (both digestive and respiratory) of the former Kabyle chicken is unanimously reported. Two persons from two different districts also mentioned the longer legs of the former varieties. White or yellow legs, as well as red plumage, were clearly associated by interviewees to the intrusion of exogenous genetics.

\section{Raising systems}

\section{Housing and feeding}

Data about raising practices are given in Table 4. Scavenging systems represented 21 percent of cases while semi-scavenging was encountered in the other 79 percent, meaning that poultry were kept sheltered at night. Shelters could be quite rudimentary and assembled

Table 3. Motivational aspects related to local poultry keeping.

\begin{tabular}{|c|c|c|c|}
\hline $\begin{array}{l}\text { Objective of } \\
\text { poultry keeping } \\
\text { activity }\end{array}$ & $\begin{array}{l}\text { Citation } \\
\text { rate }(\%)\end{array}$ & $\begin{array}{c}\text { Reasons for } \\
\text { preferring the local } \\
\text { poultry }\end{array}$ & $\begin{array}{l}\text { Citation } \\
\text { rate }(\%)\end{array}$ \\
\hline Egg production & 57.78 & $\begin{array}{l}\text { Taste of meat or } \\
\text { eggs }\end{array}$ & 88.89 \\
\hline Tradition & 53.33 & General resilience & 73.33 \\
\hline Meat production & 52.22 & Ease of raising & 65.56 \\
\hline \multirow[t]{6}{*}{ Food security } & 7.78 & Maternal behaviour & 51.11 \\
\hline & & Feather colour & 44.44 \\
\hline & & $\begin{array}{l}\text { Resistance to } \\
\text { diseases }\end{array}$ & 38.89 \\
\hline & & Longevity & 21.11 \\
\hline & & $\begin{array}{l}\text { Price premium on } \\
\text { markets }\end{array}$ & 10.00 \\
\hline & & $\begin{array}{l}\text { Biodiversity } \\
\text { conservation }\end{array}$ & 2.22 \\
\hline
\end{tabular}

Table 4. Poultry keeping system characteristics in Kabylie (citation rate in \%).

\begin{tabular}{lccr}
\hline \multicolumn{2}{c}{ Flock management } & \multicolumn{2}{c}{ Feeding } \\
\hline Semi-scavenging & 78.89 & Kitchen residue & 97.78 \\
Scavenging & 21.11 & Commercial feed & 2.22 \\
Main production purpose & Water & \\
Dual purpose & 53.33 & Wells & 47.78 \\
Egg production & 33.33 & Tap water & 43.33 \\
Meat production & 13.33 & Other ${ }^{1}$ & 8.89 \\
Use of the products & & Animals & Eggs \\
Reproduction & & 33.33 & 30.00 \\
Self-consumption & & 42.22 & 56.67 \\
Gift & 8.88 & 11.11 \\
Sale & & 12.22 & 2.22 \\
Exchange & 3.33 & 0.00 \\
\hline
\end{tabular}

${ }^{1}$ Stream, spring, fountain, etc.

from metal panels and wire netting or could be concrete constructions, often adjacent to the main habitation. Animals were mostly fed kitchen waste (98 percent). Cereals and mixes normally intended for use in complementary feeding for ruminants were seldom distributed to chickens for fattening before special celebrations ( 2 percent). The most common water sources for poultry were wells (48 percent) and tap water (43 percent).

Use of poultry products

Uses were categorized separately for animals (live animals or meat) and eggs. For animals, home consumption was the first use mentioned (42 percent). Reproduction was also a common answer (33 percent). Less cited uses were commercialization (12 percent), gift ( 9 percent) and exchange (3 percent). For eggs' use, home consumption was more common than for meat (57 percent) while commercialization was less cited ( 2 percent) and exchange was not practiced. A price premium for local poultry products was stated by 10 percent of interviewees.

\section{Morpho-biometric characterization}

Feather colour and aspect

The different colours observed and their frequencies are reported in Table 5. The most common colours were black (17 percent), white (16 percent), gold (13 percent) and silver (11 percent). Other colours such as blue, grey, mottled, red, light brown, dark red, barred, partridge, dark brown, yellow, salmon and tan were less frequently encountered (between 1 and 8 percent). Globally, the population thus turned out to be highly heterogeneous. Males were mostly white or gold (20 percent of each colour), black or silver (14 percent of each colour). In females, black (19 percent) was more frequent than white plumage (12 percent). Naked necks were seldom observed with only 4 percent of cases in both sexes. 
Table 5. Number $(n)$ and percentages (\%) of different feather colours and distribution in local chicken in Kabylie.

\begin{tabular}{|c|c|c|c|c|c|c|}
\hline & \multicolumn{2}{|c|}{ Males } & \multicolumn{2}{|c|}{ Females } & \multicolumn{2}{|c|}{ Total } \\
\hline & $N$ & $\%$ & $N$ & $\%$ & $N$ & $\%$ \\
\hline \multicolumn{7}{|l|}{ Feather colour } \\
\hline Black & 22 & 14.38 & 31 & 19.13 & 53 & 16.82 \\
\hline White & 31 & 20.26 & 19 & 11.73 & 50 & 15.87 \\
\hline Golden & 30 & 19.61 & 11 & 6.79 & 41 & 13.01 \\
\hline Silver & 21 & 13.72 & 13 & 8.02 & 34 & 10.79 \\
\hline Light brown & 5 & 3.27 & 21 & 12.96 & 26 & 8.25 \\
\hline Dark red & 7 & 4.57 & 11 & 6.79 & 18 & 5.71 \\
\hline Dark brown & 2 & 1.31 & 14 & 8.64 & 16 & 5.08 \\
\hline Barred & 5 & 3.27 & 10 & 6.17 & 15 & 4.76 \\
\hline Blue & 4 & 2.61 & 9 & 5.55 & 13 & 4.12 \\
\hline Red & 8 & 5.23 & 2 & 1.23 & 10 & 3.17 \\
\hline White Columbian black & 6 & 3.92 & 3 & 1.85 & 9 & 2.86 \\
\hline Grey & 1 & 0.65 & 6 & 3.70 & 7 & 2.22 \\
\hline Mottled & 4 & 2.61 & 2 & 1.23 & 6 & 1.90 \\
\hline Partridge & 0 & 0 & 6 & 3.70 & 6 & 1.90 \\
\hline Yellow & 3 & 1.96 & 1 & 0.62 & 4 & 1.27 \\
\hline Salmon & 2 & 1.31 & 2 & 1.23 & 4 & 1.27 \\
\hline Tan & 2 & 1.31 & 1 & 0.62 & 3 & 0.95 \\
\hline Total & 153 & & 162 & & 315 & \\
\hline \multicolumn{7}{|l|}{ Feather distribution } \\
\hline Normal & 147 & 96.08 & 155 & 95.67 & 302 & 95.87 \\
\hline Naked neck & 6 & 3.92 & 7 & 4.32 & 13 & 4.13 \\
\hline Total & 153 & & 162 & & 315 & \\
\hline
\end{tabular}

Type and colour of the comb and the wattles Comb was mostly simple (93 percent) and red (84 percent) in both sexes. The wattles were in general of the same colour as the comb and had similar colour frequencies (Table 6).

Skin and legs colour

Skin was mostly white (44 percent) but also pink (22 percent) or yellow (28 percent). Black was rare (7 percent). Legs showed the same colours but with a higher frequency of yellow (37 percent).

Table 6. Number $(n)$ and percentages (\%) of different types and colours of the comb and the wattles in local chicken in Kabylie.

\begin{tabular}{|c|c|c|c|c|c|c|}
\hline & \multicolumn{2}{|c|}{ Males } & \multicolumn{2}{|c|}{ Females } & \multicolumn{2}{|c|}{ Total } \\
\hline & $N$ & $\%$ & $N$ & $\%$ & $N$ & $\%$ \\
\hline \multicolumn{7}{|c|}{ Comb type } \\
\hline Simple & 141 & 92.16 & 153 & 94.44 & 294 & 93.33 \\
\hline Double & 8 & 5.22 & 8 & 4.93 & 16 & 5.08 \\
\hline Triple & 4 & 2.61 & 1 & 0.62 & 5 & 1.59 \\
\hline Total & 153 & & 162 & & 315 & \\
\hline \multicolumn{7}{|c|}{ Comb colour } \\
\hline Red & 138 & 90.20 & 126 & 77.77 & 264 & 83.81 \\
\hline Pink & 13 & 8.50 & 25 & 15.43 & 38 & 12.06 \\
\hline Black & 2 & 1.30 & 11 & 6.79 & 13 & 4.13 \\
\hline Total & 153 & & 162 & & 315 & \\
\hline \multicolumn{7}{|c|}{ Wattles colour } \\
\hline Red & 150 & 98.04 & 134 & 82.72 & 284 & 90.16 \\
\hline Pink & 2 & 1.31 & 16 & 9.88 & 18 & 5.71 \\
\hline Black & 1 & 0.65 & 12 & 7.40 & 13 & 4.12 \\
\hline Total & 153 & & 162 & & 315 & \\
\hline
\end{tabular}

Weight and body measurements under traditional raising system

Results for body weight and measurements are presented in Table 7. Mean weight of females was $1286 \pm 326 \mathrm{~g}$ (minimum: $805 \mathrm{~g}$; maximum: $2754 \mathrm{~g}$ ). Males were heavier with a mean weight of $1646 \pm 431 \mathrm{~g}$ (minimum: 1 060; maximum: $3241 \mathrm{~g}$ ). As for weight, all other body measurements were higher in males compared with females. Again, the population turned out to be very heterogeneous with coefficients of variation ranging from 6.8 to 65.3 percent.

\section{Performances under experimental semi-intensive system}

Egg production

Ten hens died during the experiment (16.7 percent mortality rate). The cause of this mortality has not been identified as necropsy could no be carried out. Table 8 shows the age and body weight at onset of laying, eggs number and annual laying rate. Mean age at onset was 189 days and mean body weight was $1351 \mathrm{~g}$. The hens laid a mean number of 163 eggs per year, with a laying rate of 44.6 percent. Values obtained for egg quality traits at each period are presented in Table 9. Laying rate showed a statistically significant decrease in the second period (44.68 vs 51.16 percent in the first period) while egg weight showed a statistically significant increase in this second period $(54.32 \pm 2.66$ vs $50.23 \pm 2.71 \mathrm{~g}$ in the first period). Egg component proportions did differ between periods.

\section{Growth}

Among the 160 eggs put for incubation, 111 hatched (hatching rate of 69.37 percent), and 43 males and 55 females were obtained. Mortality rate was 11.71 percent, distributed as follows: five chicks died on day 1 , two at week 2 , two at week 5 and one per week from week 9 to 12 . At week 16, mean feed conversion index was 4.97. Mean weight at hatching was $33.00 \pm 1.63$ and $31.48 \pm 2.10 \mathrm{~g}$ in males and females, respectively. At day 84 , weights were $1241.16 \pm 160.62 \mathrm{~g}$ and $1034.69 \pm 84.38$ for males and females, respectively. At day 112 , these values were $1605.56 \pm 188.42$ and 1 $284.55 \pm 102.41 \mathrm{~g}$. Gompertz growth curves for males and females are presented in Figure 1 and estimated parameters are given in Table 10. Asymptotic weight $(\alpha)$ of males was superior to that of females $(2045.30 \mathrm{~g}$ vs $1532.90 \mathrm{~g})$ as was the constant of integration $(\beta)$ (4.32 vs 4.09). The maturation rate $(\gamma)$ was higher in females, who reached their inflexion weight sooner than males (50.28 vs 56.94 days).

\section{Discussion}

\section{Socio-economic aspects}

The present study showed a clear predominance of women in poultry raising activities in households of Kabylie. Such 
Table 7. Body weight (g) and measurements ( $\mathrm{mm}$ ) according to sex and coefficient of variation in local Kabyle chicken.

\begin{tabular}{|c|c|c|c|c|}
\hline & Male $(n=153)$ & Female $(n=162)$ & Total $(n=315)$ & CV (\%) \\
\hline Body weight & $1646.46 \pm 431.25^{\mathrm{a}}$ & $1286.48 \pm 326.49^{b}$ & $1461.32 \pm 420.90$ & 28.80 \\
\hline Length of tarsus & $87.20 \pm 12.37^{\mathrm{a}}$ & $66.66 \pm 4.76^{\mathrm{b}}$ & $76.64 \pm 13.83$ & 18.06 \\
\hline Length of wing & $156.98 \pm 12.37^{\mathrm{a}}$ & $144.79 \pm 11.85^{\mathrm{b}}$ & $150.71 \pm 13.43$ & 8.91 \\
\hline Diameter of tarsus & $15.39 \pm 1.21^{\mathrm{a}}$ & $12.10 \pm 1.25^{\mathrm{b}}$ & $13.70 \pm 2.05$ & 15.00 \\
\hline Thoracic perimeter & $403.23 \pm 25.23^{\mathrm{a}}$ & $374.95 \pm 18.97^{\mathrm{b}}$ & $388.68 \pm 26.33$ & 6.77 \\
\hline Body length & $417.04 \pm 18.00^{\mathrm{a}}$ & $370.52 \pm 17.70^{\mathrm{b}}$ & $393.12 \pm 29.31$ & 7.46 \\
\hline Comb height & $33.25 \pm 4.84^{\mathrm{a}}$ & $11.87 \pm 4.61^{\mathrm{b}}$ & $22.26 \pm 11.69$ & 52.55 \\
\hline Beak length & $34.40 \pm 2.84^{\mathrm{a}}$ & $31.58 \pm 2.06^{\mathrm{b}}$ & $32.95 \pm 2.84$ & 8.62 \\
\hline Comb length & $69.49 \pm 8.29^{\mathrm{a}}$ & $31.46 \pm 3.32^{\mathrm{b}}$ & $49.93 \pm 20.03$ & 40.12 \\
\hline Wattles length & $33.90 \pm 3.67^{\mathrm{a}}$ & $7.92 \pm 2.88^{\mathrm{b}}$ & $20.54 \pm 13.41$ & 65.28 \\
\hline
\end{tabular}

a,b: On a same line, different letters are assigned to values showing statistically significant differences between them $(p<0.05)$.

$\mathrm{CV}$ : coefficient of variation.

a gender bias has been reported in many other developing countries (Gueye, 2007; Keambou et al., 2007; Ramdas, 2009). This bias is the rationale for the use of poultrykeeping programmes as a means of targeting women in poverty alleviation projects, an approach widely known as the "Bangladesh smallholder poultry model" (Jensen and Dolberg, 2003). As highlighted by Kitalyi (1998), the gender bias is not universally true and must be accordingly investigated as a precondition for the effectiveness of those programmes. Further attention must be paid to the fact that poultry keeping is neglected by men as long as it is oriented towards home consumption and does not bear any hope for profit. If cash earnings can be realized, men could then intervene in the management and selling decisions to the detriment of women (Gueye, Ndiaye and Branckaert, 1998). As a matter of fact, in Kabylie, larger semi-intensive or intensive poultry farms are mostly run by men. The monitoring of gender issues throughout the development of access of smallholders to the poultry markets is thus necessary. Upstream, the access to production factors, capital, credit and decision-making become pivotal gender questions if the development of this value chain is to benefit women. In the present survey, it has been difficult and sometimes impossible in many households to interview women directly despite their recognized role in poultry keeping in those households. This sheds light on the gender problem in this region and the many difficulties that would be encountered by projects designed to empower rural women.

A clear lack of education among poultry smallholders also appeared in the present survey. This lack should be

Table 8. Laying performance of local Kabyle hen under experimental semi-intensive conditions $(n=50)$

\begin{tabular}{lrrrr}
\hline & Mean & \multicolumn{1}{c}{ SD } & \multicolumn{1}{c}{ Max } & \multicolumn{1}{c}{ Min } \\
\hline BW at first egg (g) & 1351.00 & 100.24 & 1521.00 & 1150.00 \\
Age at first egg (days) & 188.72 & 16.96 & 214.00 & 159.00 \\
Eggs layed per year & 162.64 & 27.06 & 202.00 & 115.00 \\
Annual laying rate (\%) & 44.56 & 7.49 & 55.34 & 31.51 \\
\hline
\end{tabular}

SD: standard deviation; BW: body weight. addressed in any project aiming at improving poultry keeping practices and organizing producers. Indeed, education is a fundamental determinant of the ability of people to organize themselves and build the institutions needed for sustainable economic development. At present, basic scholarship is obligatory in Algeria but illiteracy remains a real problem in men and women in rural areas.

Chicken flocks owned by the sampled households were small, none of them exceeding 30. All households owned other agricultural assets such as animals, fruit trees, beehives or cropland. No clear grouping of households could be distinguished through principal component analysis and hierarchic classification (results not shown). Thereby, the households included in the survey appeared to be quite homogeneous regarding the diversity of agricultural occupations. In accordance with this global diversification of agricultural assets, attention should be paid to the change in factor allocation (mainly labour) ensuing from improvements in the raising system. For example, women are traditionally engaged in milking of cattle or goats, and may not be able to spend additional time on poultry raising or commercialization as men make

Table 9. Laying and egg quality parameters in local Kabyle hen under experimental semi-intensive conditions $(n=50)$.

\begin{tabular}{lrrrrr}
\hline & \multicolumn{3}{c}{ Mean \pm SD } & \multirow{2}{*}{ t-value } \\
\cline { 2 - 3 } & 38-42 weeks & $\mathbf{5 6 - 6 0}$ weeks & & \\
\hline Laying rate (\%) & $51.16 \pm 10.97$ & $44.68 \pm 8.29$ & 3.37 & $*$ \\
Egg weight (g) & $50.23 \pm 2.71$ & $54.32 \pm 2.66$ & 7.71 & $* * *$ \\
Albumen weight (g) & $29.01 \pm 1.87$ & $31.34 \pm 1.86$ & 6.27 & $* * *$ \\
Yolk weight (g) & $15.36 \pm 1.01$ & $16.81 \pm 1.30$ & 6.20 & $* * *$ \\
Shell weight (g) & $5.86 \pm 0.59$ & $6.18 \pm 0.80$ & 2.24 & $*$ \\
Albumen percentage (\%) & $57.73 \pm 1.51$ & $57.69 \pm 1.78$ & 0.13 & ns \\
Yolk percentage (\%) & $30.59 \pm 1.38$ & $30.93 \pm 1.86$ & 1.05 & ns \\
Shell percentage (\%) & $11.68 \pm 1.08$ & $11.38 \pm 1.41$ & 1.20 & ns \\
Shell thickness (10 $0^{-2}$ mm) & $36.34 \pm 2.40$ & $35.04 \pm 4.31$ & 1.86 & ns \\
Shape index ${ }^{1}$ & $75.50 \pm 1.99$ & $74.85 \pm 2.37$ & 1.47 & ns \\
Y:A ratio (\%) & $52.82 \pm 3.71$ & $53.53 \pm 4.24$ & 0.60 & ns \\
\hline
\end{tabular}

1: Egg length/width $\times 100$.

Y:A: yolk-to-albumen ratio.

$\mathrm{ns},{ }^{*}, * * *: p>0.05, p<0.05, p<0.0001$, respectively. 


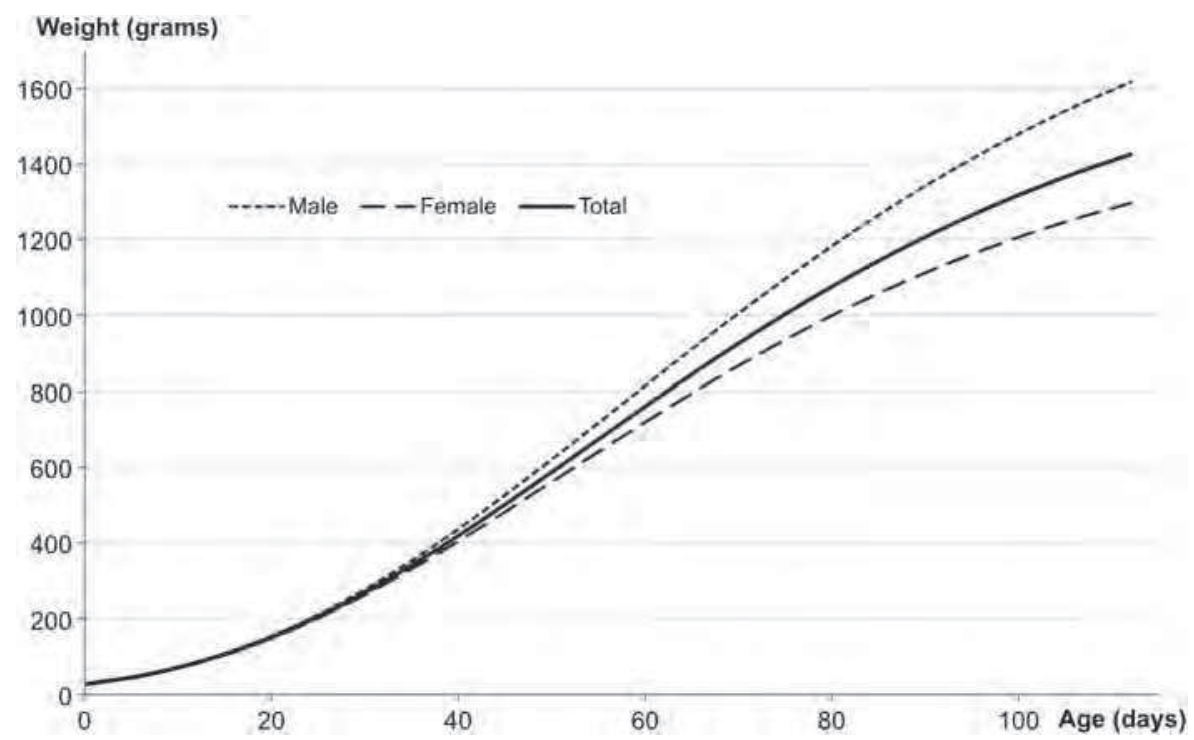

Figure 1. Gompertz growth curve parameters of local Kabyle chicken under experimental semi-intensive conditions.

decisions on the asset-diversification strategy of the household.

\section{Motivations for poultry raising and indigenous genetic resources management}

Poultry is primarily kept for home consumption of both eggs and meat. The fact that the tradition purpose comes as a frequent answer is interesting, showing the cultural and social importance of the simple owning of some hens in Kabylie. Reasons for preference for local chickens over commercial ones could be regarded as a first approximation of breeding goals. Resilience, ease of raising and flavour of eggs and meat are the principal motives. The first two statements fit into the general conception of poultry keeping as a low-investment, low-cost, low-risk and low-skill side activity. The great variety of phenotypes recorded through morpho-biometric descriptions might also point out a lack of management of genetic resources in accordance with the general tendency not to invest in poultry. The present erosion of these genetic resources can be estimated in this study from the percentage of black and blue legs in the total population, which barely attains 14 percent. Erosion can thus be considered as very advanced. Summing up the frequencies of the plumage colours cited as being those of the "true Kabyle chicken" by elders, a total of 29.5 percent is obtained.

Table 10. Gompertz growth curve parameters of local Kabyle chicken under experimental semi-intensive conditions.

\begin{tabular}{lcccc}
\hline Sex & \multicolumn{4}{c}{ Gompertz curve's parameter } \\
\cline { 2 - 5 } & $\boldsymbol{\alpha}(\boldsymbol{g})$ & $\boldsymbol{\beta}$ & $\gamma$ (day $\left.^{-\mathbf{1}}\right)$ & $\boldsymbol{T}$ (days) \\
\hline Males & 2045.30 & 4.320 & 0.0257 & 56.94 \\
Females & 1532.90 & 4.087 & 0.0280 & 50.28 \\
\hline
\end{tabular}

While black on its own is still relatively frequent (almost 17 percent), the barred, mottled, blue and partridge phenotypes hardly reach a combined frequency of 12.7 percent.

Such an observation might be misleading about the true interest of local people in their poultry genetic resources. Indeed, an important share of respondents mentioned the colour of feathers to be a case for preference of the local chicken, which denotes cultural importance for the local type. However, this preference is apparently not strong enough to neutralize economic incentives for genetic resource wastage, as described below. Answers from experienced raisers tend to show that the Kabyle chicken previously had a well-standardized phenotype with a quite restricted number of different varieties.

The reported period of change corresponds to the rapid development of industrialized poultry farms in Algeria as a result of the general process of liberalization and privatization of economic activities under the Structural Adjustment Programme imposed by the International Monetary Fund in 1994. From this time onwards a double incentive led to erosion of local poultry genetic resources. First, even in rural villages, people gained access to lowcost eggs and poultry meat, which consequently reduced incentives for keeping large flocks at home in numerous households and especially in those that had the best access to markets. Then the culled layer hens from the industrialized sector were sold on markets and used by households to get an easy and rapid increase of egg production in their own flock.

It appears from the additional survey that in the past poultry raisers implemented some selection in order to increase egg production. The rapid increase obtained by crossbreeding was further reduced incentives for improvement of local chickens. Finally, the erosion process involves externalities linked to the quasi-public good nature of animal genetics (Roosen, Fadlaoui and Bertaglia, 2005). 
Indeed, a reduction in the number of households keeping the local chicken resulted in a drastic cut in the local genetic pool, realized by a decrease in the number of local poultry eggs sold for hatching in village markets, as reported by some experienced raisers in the survey. This led to reduced access to local chickens by the poorest smallholders that needed them to increase their flocks and a strong incentive for "intensification" of their flock by introducing culled birds from industrial strains.

\section{Performance in an experimental semi-intensive system}

\section{Egg production}

The mortality rate during this study was high, which could be ascribed to the inadequacy of housing in cages for local hens. However, Benabdeljelil, Lahbabi and Bordas (2003) reported higher mortality rates in a similar experience in Morocco, rearing cross-bred Egyptian Fayoumi $\times$ Leghorn and Mandarah $\times$ ISA hens in cages (26.7 and 19.3 percent, respectively). Onset of laying occurred at 189 days. Among local breeds of the Maghreb, this appears late compared with the Mandarah hen, an Egyptian breed, which starts laying at 139 days, as well as to the Moroccan local hen, which start laying at 174 days (Raach-Moujahed et al., 2011). However, the present individual production of 163 eggs per year is higher than that of the different known local breeds of the Maghreb, namely the Dandarawi (Egypt, 128 eggs/year) and the Fayoumi (Egypt, 141 eggs/year) (Raach-Moujahed et al., 2011), as well as Tunisian and Moroccan local hen (127 and 78 eggs per year, respectively) (Raach-Moujahed et al., 2011). The decrease of production in the second period is in accordance with the known evolution of productive performance in commercial strains. The rate of laying commonly reaches a peak and then declines until the end of the production cycle. The egg weight of over $50 \mathrm{~g}$ represents a very good performance compared with other local hens of the region such as the Fayoumi (42-47 g) in Egypt (Hossary and Galal, 1995; Raach-Moujahed et al., 2011) or the Large Baladi (38.5 $\mathrm{g})$, the Bare-Neck (39.4 g) and the Betwil (38 g) in Sudan (Mohammed et al., 2005). The yolk-to-albumen ratio (52.8 percent) is high compared with commercial strains. This is a known feature of local hens, and this ratio is usually negatively correlated to egg weight (Moula et al., 2010). The increase in egg weight that was observed between the two periods represented an increase of both yolk and albumen, as also reported in the literature (Hartmann et al., 2000; Silversides and Budgell, 2004). Thus the yolk-to-albumen ratio did not show a statistically significant difference between periods.

\section{Growth}

The hatching rate was low, being below 70 percent, whereas rates are considered normal at 80 percent (Sonaiya and Swan, 2004). The effects on growth of age, sex and their interaction were all highly significant $(p<$ $0.0001)$. Two different growth curves are presented for males and females (Table 10), as sexual dimorphism is a known characteristic of chicken (Pedersen et al., 2003). At 16 weeks, the body weight of the Kabyle chicken was satisfactory, being superior to those reported for local chickens in Tunisia by Bessadok, Khochilef and El Gazzah (2003). The feed conversion index was high (4.97) compared with values recommended for slowgrowing quality broiler such as the French "Label Rouge" (Sauveur, 1997) but were in the same range as values reported for other local breeds such as the Ardennaise chicken in Belgium (Moula et al., 2009b).

\section{Conclusion}

The local poultry genetic resources of Kabylie are shown here to be undergoing serious erosion. As advocated by Anderson and Centonze (2007), collective action for the conservation of animal genetic resources is only possible where those resources are central to people's livelihoods. This importance of the Kabyle chicken is shown here to have both economic and cultural elements, and the case of the Kabyle chicken is accordingly proposed to be manageable on the condition that the identified stakeholders get effective technical and organizational support. The constitution of a breed society might be proposed in this context. On a practical side, the revival of a local chicken breed might first focus on the black phenotypes. Pure black, barred and mottled individuals should then be included in a mixed genetic pool. The blue plumage individuals might also be included in this base population, according to an inclusive strategy for genetic diversity management. Beside this first consolidation phase, objectives of the rearing system should be clarified with the stakeholders, leading to the definition of breeding goals that should govern a sustained selection effort. In this context, the opportunity for some degree of semiintensification should be carefully considered. Such systems would need differentiated markets, which could be envisaged if the reported price premium for local products is confirmed. Indeed, chicken is notably consumed at feasts in Kabyle tradition (New Year, first day of spring) and quality products could benefit from this traditional support. The present performance of the indigenous chicken appears to be competitive with other breeds and local types of the Maghreb. However, the primary interest of the testing conditions in this study was experimental. Semi-intensification on the field should be more gradual and would possibly involve less advanced forms.

\section{References}

Anderson, S. 2003. Animal genetic resources and sustainable livelihoods. Ecol. Econ., 45: 331-339. 
Anderson, S. \& Centonze, R. 2007. Property rights and the management of animal genetic resources. World Dev., 35: 1529-1541.

Benabdeljelil, K., Lahbabi, S. \& Bordas, A. 2003. Comparaison de croisements incluant une race locale ou une lignée expérimentale à un témoin commercial pour la production d'œufs au Maroc. Rev. d'Elevage Méd. Vétér. Pays Tropicaux, 56: 193-198.

Bessadok, A., Khochilef, I. \& EI Gazzah, M. 2003. Etat des ressources génétiques de la population locale du poulet en Tunisie. Tropicultura, 21: $167-172$.

FAO. 1981. Descripteurs des espèces avicoles. In Banque de données des ressources génétiques animales. pp. 13-15. Rome.

FAO. 2008. The state of the world's animal genetic resources for food and agriculture. In Rischkowsky, B. \& Pilling, D. eds. Rome.

Gueye, E.F., Ndiaye, A. \& Branckaert, R.D.S. 1998. Prediction of body weight on the basis of body measurement in mature indigenous chickens in Senegal. Livestock Research for Rural Development, 10 (available at http://www.1rrd.org/lrrd10/3/sene103.htm.)

Gueye, E.F. 2007. Evaluation of the impact of HPAI on family poultry production in Africa. World's Poult. Sci. J., 63: 391-400.

Hartmann, C., Johansson, K., Strandberg, E. \& Wilhemson, M. 2000 One-generation divergent selection on large and small yolk proportions in a White Leghorn Line. Br. Poult. Sci., 41: 280-286.

Hossary, M.A. \& Galal, E.S.E. 1995. Improvement and adaptation of the fayoumi chicken. Anim. Genet. Resour. Inform., 14, 33-42.

Jensen, H.A. \& Dolberg, F. 2003. A conceptual framework for using poultry as a tool in poverty alleviation. Livestock Research for Rural Development, 15 (available at http://www.lrrd.org/lrrd15/5/ jens155.htm).

Keambou, T.C., Manjeli, Y., Tchoumboue, J., Teguia, A. \& Iroume, R.N. 2007. Caractérisation morpho-biométrique des ressources génétiques de poules locales des hautes terres de l'ouest Cameroun. Livestock Research for Rural Development, 19 (available at http:// www.lrrd.org/lrrd19/8/keam19107.htm).

Kitalyi, A. 1998. Village chicken production systems in rural Africa: Household food security and gender issues. FAO Animal Production and Health paper 142. Food and Agriculture Organization of the United Nations, Rome, 105 pp.

Mack, S., Hoffmann, D. \& Otte, J. 2005. The contribution of poultry to rural development. World's Poult. Sci. J., 61: 7-14.

Mohammed, M.D., Abdasalam, Y.I., Kheir, A.M., Wang, J.Y. \& Hussein, M.H. 2005. Comparison of the egg characteristics of different Sudanese indigenous chicken types. Int. J. Poul. Sci., 4: 455-457.
Moula, N., Antoine-Moussiaux, N., Farnir, F., Detilleux, J. \& Leroy, P. 2009a. Réhabilitation socioéconomique d une poule locale en voie d 'extinction: la poule Kabyle (Thayazit lekvayel). Ann. Méd. Vétér. 153: $178-186$.

Moula, N., Antoine-Moussiaux, N., Farnir, F., Philippart De Foy, M. \& Leroy, P. 2009b. Performances zootechniques de la poule Ardennaise, une race ancienne pour le futur? Ann. Méd. Vétér., 153: $66-75$

Moula, N., Antoine-Moussiaux, N., Decuypere, E., Farnir, F. Mertens, K., De Baerdemaeker, J. \& Leroy, P. 2010. Comparative study of egg quality traits in two Belgian local breeds and two commercial lines of chickens. Arch. Geflügelkunde, 74: 164-171.

Pedersen, M.A., Thamsborgs, S.M., Fisker, C., Ranvig, H. \& Christensen, J.P. 2003. New production systems: evaluation of organic broiler production in Denmark. J. Appl. Poult. Res., 12: 493-508.

Porter, T., Kebreab, E., Kuhi, H.D., Lopez, S., Strathe, A.B. \& France, J. 2010. Flexible alternatives to the Gompertz equation for describing growth with age in turkey hens. Poult. Sci., 89, 371-378.

Raach-Moujahed, A., Moujahed, N. \& Haddad, B. 2011. Local poultry populations in Tunisia: present and alternatives. A review. Livestock Research for Rural Development, 23 (available at http://www.lrrd. org/lrrd23/4/raac23096.htm).

Ramdas, S.R. 2009. Reclaiming endangered livelihoods: untold stories of indigenous women and backyard poultry. World's Poult. Sci. J., 65: 241-250.

Roosen, J., Fadlaoui, A. \& Bertaglia, M. 2005. Economic evaluation for conservation of farm animal genetic resources. J. Anim. Breed. Genet., 122: 217-228.

Roothaert, R.L., Ssalongo, S. \& Fulgensio, J. 2011. The Rakai chicken model: an approach that has improved fortunes for Ugandan farmers. Int. J. Agric. Sustain., 9: 222-231.

Sauveur, B. 1997. Les critères et facteurs de la qualité des poulets Label Rouge. Product. Anim., 10: 219-226.

Silversides, F.G. \& Budgell, K. 2004. The relationships among measures of egg albumen height, $\mathrm{pH}$ and whipping volume. Poult. Sci., 83: 1619-1623.

Sonaiya, E.B. \& Swan, S.E.J. 2004. Small-scale poultry production. Food and Agriculture Organization of the United Nations, Rome, 125 pp.

Statistical Analysis System Institute. 2000. SAS/STAT User's Guide. Version 8. SAS Inst. Inc., Cary, NC. 